\title{
The Patterning of Segments and Tones in Èwùlù Compounding Process
}

\author{
Utulu, Don C., Ph.D.* \\ Lecturer, Department of Languages and Linguistics, Delta State University, Abraka, Nigeria.
}

*Corresponding Author: Utulu, Don C., Ph.D., Lecturer, Department of Languages and Linguistics, Delta State University, Abraka, Nigeria

\begin{abstract}
This paper investigates the phonological patterning of segments and tones in compound words in Èù̀ù. Compounding is a morphological process whereby two or more free morphemes, or words are combined to form compound words. In the study of the Ėwùlù compounding processes, it was discovered that some segmental processes such as vowel deletion, glide formation and vowel nasalisation occurred. In addition it was observed that a number of tonal processes such as boundary vowel deletion, tone contraction, tone segmentalisation and final high tone downstepping occurred. In its final discussions, this paper, largely inspired by the need to document Nigerian small languages with less than 100,000 native speakers (Ėwùlù inclusive), recommends the need for indigenous Nigerian small languages to be rigorously studied, documented and developed, if they, on the one hand, must continue to exist, and on the other hand, if they must functionally compete favoruably with Nigerian bigger languages such as Hausa, Yoruba and Igbo in national affairs.
\end{abstract}

Keywords: Nigerian (Small)Languages, Èwùlù, Compounding Process, Segmental Processes, Tonal Processes

\section{INTRODUCTION}

Èwùlù is a language spoken by a people also known by the name. It is a small language-small in the sense that, demographically, it has approximately about 15,000 native speakers, with a sizeable number of youths, who day-to-day drift to metropolitan areas in search of jobs to earn a living. Ėwùlù is one of the dialect clusters of the Énúànì group of languages spoken in the Northern part of Delta State, Nigeria. The group occupies the western part of the River Niger. Other groups forming part of the clusters of dialects are İ̀ká and Ứkwứanị. The Énúànì-İ̀ká-Ứkwụ́anì group is sometimes referred to as "Delta Igbo" or "Western Igbo", (Emenanjo, 1978; Utulu, 2014) wing to their close linguistic affinity with the Eastern Igbo varieties spoken in the East of the Niger River.

Due to dearth of linguistic, historical and anthropological research studies, coupled with the general negative attitude of Ėwùlù youths toward the use of Ėwùlù in their daily life activities, the language is seriously under the threat of extinction. In order to stem the imminent death of this language and hence ensure its survival, the researcher, who is a native speaker of Èwùlù, investigates the mode of deriving new words via compounding process. Moreover, because morphological patterning often affects phonological units which are the compositions of the concatenated morphemes themselves, a number of attested segmental and tonal processes are explored.

In the final discussions of the paper, the researcher strongly recommends the need for indigenous Nigerian languages, particularly the very small languages (Èwùlù inclusive) to be developed and documented, bearing in mind that, as Williamson (1992) opined, that the fate of small languages is in the hands of their speakers. If they wish their language to grow and develop, they should take steps not only to use [study] it themselves but to ensure that their children are adequately exposed to it and retain it as their home language to pass on to the next generation. It is on the basis of this advice that this work is carried out. It is expected that if Èwùlù as well as other endangered small languages in Nigeria are given the required research and documentational attention, it will be able to compete with big languages such as Hausa, Yoruba and Igbo in national affairs, and with English, French, German, Italian, Spanish, Japanese and Chinese in international affairs.

\section{Compounding}

Compounding is a morphological process whereby two or more potentially free morphemes or words are combined to form new words (Katamba, 1993; Fabb, 2001; Aikhenvald, 2007; Iloene and Yusuf, 
2010). The newly formed words are referred to as compound words. Èwùlù provides some fascinating patterns of compounding which, as will be shown later, confirm the fact that compounding is nothing more than a linguistic process which reflects the inventive, creative and productive nature of the human language. For instance, in Èwùlù, string of words which are equivalent to the sentence can be combined to form a single new word. Words in this category are forenames and numerals, which have been reported in (Kwa/Niger Congo) languages (Welmers, 1973).

Generally, the most common pattern of forming compounds in Èwùlù is by systematically combining two free morphemes in the noun class, verb class, adjective class and preposition class. The conflation of morphemes/words may involve the combination of a noun with another noun, a verb with another verb, a noun with an adjective and so on. With such combinations, compounds can be used for descriptive purposes; and others as modifiers or intensifiers. One other interesting aspect of compounding process is coarticulation effects on boundary segments (usually vowels), during fast speech. The effect invariably triggers some segmental processes which in turn affect the tone which the segments bear, since the affected juncture vowels are phonologically specified for the tone. Consequently it is common to find the lexical tones modified alongside the operations of the segmental processes which include (1) vowel deletion, (2) glide formation, and (3) vowel nasalisation. These structural changes thus confirm the existing interface between morphology and phonology across languages.

\subsection{Derivation of Compound Words in Èwùlù}

As mentioned earlier, most compound words in Èwùlù are derived by combining different word categories such as nouns, adjectives, verbs and prepositions. A noun can combine with another noun. In the same vein, a verb may combine with another verb or even a noun. Likewise, a preposition may combine with a noun, though relevant data show that fewer compounds are derived from prepositionnoun combination in Èwùlù. This appears to be traced to the fact that few prepositions are attested in the language, as is obtained in other languages, when compared with nominal and verbal compounding. Some of the procedures utilised in deriving compounds in Èwùlù are examined below.

\subsection{Derivation of Noun-plus-Noun Compounding}

Noun-noun compounding also known as nominal compounding is a compounding process which involves the combination of nominal morphemes. In Èwùlù two independent nouns can be combined to form nominal compounds. Functionally, they are used for descriptive purpose in the language. The procedure of deriving nominal (noun-noun) compounds is shown in (1) as follows:

\begin{tabular}{|c|c|c|c|c|c|c|c|c|}
\hline \multicolumn{9}{|c|}{ Noun + Noun Compounding } \\
\hline \multicolumn{5}{|c|}{ Basic Forms } & & \multicolumn{3}{|c|}{ Phonetic Form } \\
\hline (1) & & Noun & & Noun & & \multicolumn{3}{|c|}{ Nominal Compoud } \\
\hline & i. & ónyé & + & ńkúzí & $\rightarrow$ & ónyéńkúzí & $\rightarrow$ & [óné́ńkúzí] \\
\hline & & 'person' & & 'teach-ing' & & 'teacher' & & \\
\hline & ii. & ḿkpụ́!lụ́ & + & ósísí & $\rightarrow$ & ḿkpụ́!!ụ́ósísí & $\rightarrow$ & [ḿpó!!wósísí] \\
\hline & & 'seed' & & 'stick/tree' & & 'fruit' & & \\
\hline & iii. & éká & + & ṇín & $\rightarrow$ & ékánírí & $\rightarrow$ & [ćkáń!rí] \\
\hline & & 'hand' & & 'food' & & 'right hand' & & \\
\hline & iv. & ókwú & + & Ónụ́ & $\rightarrow$ & ókwúớ!nụ́ & $\rightarrow$ & [ókwúó!nứ] \\
\hline & & 'word' & & 'mouth' & & 'utterance' & & \\
\hline & $\mathrm{v}$. & ứgbó & + & ànì & $\rightarrow$ & ứgbớànì & $\rightarrow$ & [úbwânİ] \\
\hline & & 'canoe' & & 'land' & & 'automobile' & & \\
\hline & vi. & è̀shụ́ & + & ókwứ & $\rightarrow$ & è̀shụ́ọ́!kwụ́ & $\rightarrow$ & [غे〔wó!kwứ] \\
\hline & & 'body' & & 'fire' & & 'fever' & & \\
\hline & vii. & ágụ́ & + & ǹtkwó & $\rightarrow$ & àgứṇ!!kwọ́ & $\rightarrow$ & [ágớń!kwó] \\
\hline & & 'tiger' & & 'first day of the week' & & 'eagle' & & \\
\hline & viii. & ǹmányá & + & ṇ́kứ & $\rightarrow$ & mmányáṇ! !kụ & $\rightarrow$ & [mmã́nã́ń!kư] \\
\hline & & 'wine' & & 'wood' & & 'palmwine' & & \\
\hline & ix. & è̀shụ́ & + & ụ́nò & $\rightarrow$ & èsshứúnọ̀ & $\rightarrow$ & 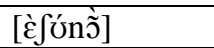 \\
\hline & & 'body' & & 'house' & & 'wall' & & \\
\hline & $\mathrm{x}$. & è̀kpà & + & ǹnwwá & $\rightarrow$ & è̀kpàṇ́!nwá & $\rightarrow$ & [غ̇pàń!nwã́] \\
\hline & & 'bag' & & 'child' & & 'womb' & & \\
\hline
\end{tabular}

Note: The letter $\langle\mathrm{n}\rangle$ stands for syllabic nasals, $[\mathrm{n}],[\mathrm{m}],[\mathrm{n}]$ and $[\mathrm{n}]$. The sequence $\langle\mathrm{ny}\rangle,\langle\mathrm{kp}\rangle$ and $\langle\mathrm{gb}\rangle$ are digraphs representing the sounds, $[\mathrm{n}],[\mathrm{p}]$ and [6] respectively. The sequence $<$ nw $>$ stands for the sound [yw]. 
It will be noticed that in the examples (as is the case with subsequent examples examined in this work), the combination of two noun items yields full morpheme or word. Besides, it will be noticed that in the combination process, some vowels are modified: some are deleted; some are converted to a glide, while some are nasalised, particularly vowel preceded by nasal consonant. These three instances of segmental modification have been tagged vowel deletion (elision), glide formation and vowel nasalisation respectively. Moreover, it will be observed that some lexical tone structures are modified. Crucially, the observed modifications have implication for the well-known interface between morphology and phonology in languages, processes which will be discussed in the later sections of this work.

Besides, Èwùlù can derive nominal compound words by simply combining nouns with adjectives. Such a combination has descriptive function and may reflect emotions/feelings, positive or negative. Examples are presented in (2) as follows:

\begin{tabular}{|c|c|c|c|c|c|c|c|c|}
\hline \multicolumn{9}{|c|}{ Noun + Adjective Compounding } \\
\hline \multirow{2}{*}{\multicolumn{6}{|c|}{ Basis Forms }} & \multicolumn{3}{|c|}{ Phonetic Form } \\
\hline \multirow[t]{2}{*}{ (2) } & & & & Adjective & & \multicolumn{3}{|c|}{ Nominal Compound } \\
\hline & i. & Ísí & + & íké & $\rightarrow$ & ísíí!ké & $\rightarrow$ & [ísí!ké] \\
\hline & & 'head' & & 'hard' & & 'stubbornness' & & \\
\hline & ii. & ényá & + & úkwú & $\rightarrow$ & ényáúkwú & $\rightarrow$ & [ćnứkwú] \\
\hline & & 'eye' & & 'big' & & 'greed' & & \\
\hline & iii. & ếká & + & íké & $\rightarrow$ & ékáíké & $\rightarrow$ & [ع́kí!ké] \\
\hline & & 'hand' & & 'hard' & & 'stinginess' & & \\
\hline & iv. & Ísí & + & ómá & $\rightarrow$ & ísíómá & $\rightarrow$ & [í́sjómấ] \\
\hline & & 'head' & & 'beautiful' & & 'good-luck' & & \\
\hline & $\mathrm{v}$. & ónwú & + & íké & $\rightarrow$ & ónwúíké & $\rightarrow$ & [ónwí!ké] \\
\hline & & 'death' & & 'hard/power' & & 'unnatural deat & & \\
\hline
\end{tabular}

Like in (1), as can be seen in (2), the phonetic forms of the compounds of emotions/feelings in the last column display some segmental and tonal processes: specifically, hiatus resolution, tone contraction and final high tone downstep. See discussions of these tonal processes in section 3.

Furthermore, in Èwùlù, compound words can be derived by simply conjoining prepositions and nouns. Functionally, preposition-noun compounds are typically used to express certain items which are otherwise impossible to express unsing a single word. Examples are presented in (3) as follows:

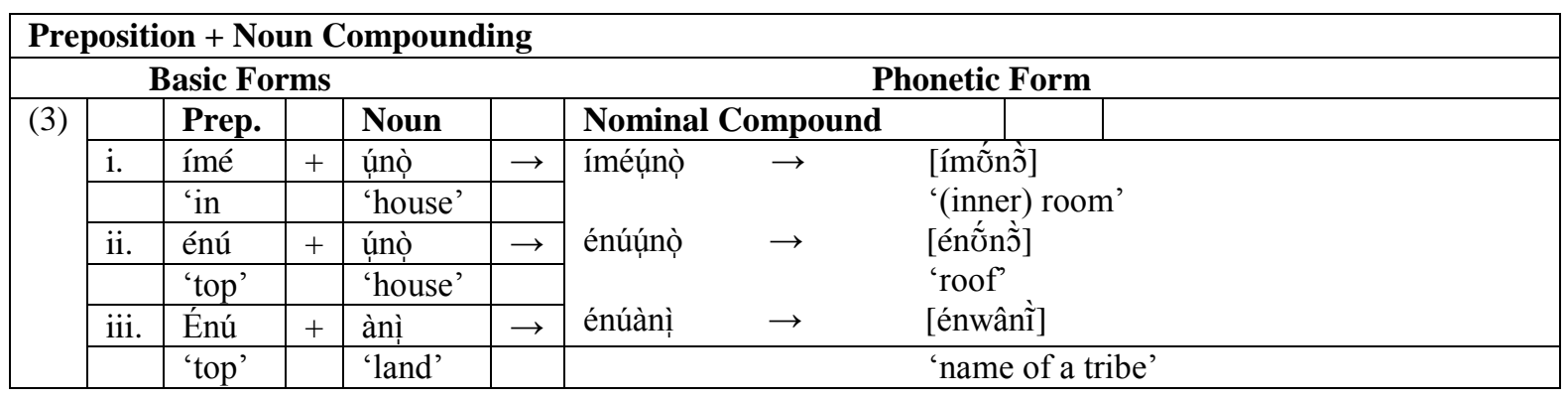

Like mentioned earlier, words formed by this procedure are few in the language, and that is because Èwùlù, as in many languages, has fewer number of prepositions when compared with nouns, adjectives and verbs.

Besides, Èwùlù operates verbal compounds which are derived by combining two simple verb stems. Compound words in this category express an action which is essentially not expressible using a single simple verb stem. Compound words of this sort create a sense of 'intensification' or 'modification' of an action. This process is shown in (4) as follows:

\begin{tabular}{|l|l|l|l|l|l|l|}
\hline \multicolumn{7}{|c|}{ Verb + Verb Compounding } \\
\hline \multicolumn{5}{|c|}{ Basic Forms } \\
\hline$(4)$ & \multicolumn{3}{|c|}{ Verb } & & Verb & \multicolumn{3}{l|}{ Perbal compounding } \\
\hline & i. & tí & + & gbú & $\rightarrow$ & [tíbú] \\
\hline & & 'beat' & & 'kill' & & 'lynch' \\
\hline & ii. & nó & + & gbú & $\rightarrow$ & [ñ̂́bú] \\
\hline & & 'press' & & 'kill' & & 'massage intensely' \\
\hline & iii. & gbá & + & wá & $\rightarrow$ & [6áwá] \\
\hline & & 'shoot' & & 'split' & & 'break (an hollow object)' \\
\hline
\end{tabular}


The Patterning of Segments and Tones in Èwùlù Compounding Process

\begin{tabular}{|l|l|l|l|l|l|l|}
\hline & iv. & tí & + & wá & $\rightarrow$ & [tíw'́] (or [tíwá] for some speakers) \\
\hline & & 'beat' & & 'split' & & 'break (a ceramic plate)' \\
\hline & v. & kà & + & gbú & $\rightarrow$ & [kà6ú] \\
\hline & & 'mark' & & 'kill' & & 'erase/cancel (a written text)' \\
\hline & vi. & ké & & mé & $\rightarrow$ & [kémé] 'tie (a thing)' \\
\hline & & tie & & make & & \\
\hline
\end{tabular}

As shown in the compound words presented so far, it will be noticed that all of them have descriptive function.

Moreover, some category of nominal compound words are derived by a combination of a noun and a verb, which are also descriptive in fuction. For instance, to derive certain kind of nominal compounds which are functionally descriptive, the language simply combines agentive noun (a noun derived from prefixed and suffixed simple verb stems (see forms in bold print in (5) and denotes performer of an action, (see Emenanjo, 1978)) with simple noun. Examples are presented in (5) as follows:

\begin{tabular}{|c|c|c|c|c|c|c|c|c|}
\hline \multicolumn{9}{|c|}{ Agentive Noun + Simple Noun Compounding } \\
\hline \multicolumn{6}{|c|}{ Basic Forms } & \multicolumn{3}{|c|}{ Phonetic Form } \\
\hline$(5)$ & \multicolumn{3}{|c|}{ Agentive Noun } & \multicolumn{2}{|c|}{ Simple Noun } & & & \\
\hline & i. & ò-gbú-ù & + & èbùnù & $\rightarrow$ & ògbúùèbùnù & $\rightarrow$ & [òb(w)êbùnũ்] \\
\hline & & 'killer & & 'ram' & & 'ram killer' & & 'native doctor' \\
\hline & ii. & ò-ché-è & + & ụ́nọ̀ & $\rightarrow$ & òchéèứnọ & $\rightarrow$ & [òtyûnõ்] \\
\hline & & 'guard' & & 'house' & & 'house guard' & & 'gecko' \\
\hline & iii. & ò-gbú-ù & + & ánụ́ & $\rightarrow$ & ògbúùánụ́ & $\rightarrow$ & [òbwânữ] \\
\hline & & 'killer' & & 'meat' & & 'meat killer' & & 'butcher' \\
\hline & iv. & ò-gbú-ù & + & éfí & $\rightarrow$ & ògbúùéfí & $\rightarrow$ & [òbwê!fí] \\
\hline & & 'killer' & & 'buffalo' & & 'buffalo killer' & & hieftaincy title' \\
\hline & $\mathrm{v}$. & ò-rí-ì & + & ǹgwélè & $\rightarrow$ & òríìngwélè & $\rightarrow$ & [òrî̀ǹgwēlē] \\
\hline & & 'eater' & & 'lizard' & & 'lizard eater' & & ype of bird' \\
\hline
\end{tabular}

Again, like the phonetic forms of compounds espoused in the foregoing, both segments and tones are inevitably altered under the operation of compounding process.

The formation of compound words is not restricted to two-morpheme/word elements. Certain kind of compound words may be generated when more than two free morphemes are combined. Compounds in this category in Ėwùlù are typically forenames and numerals. The respective prototypes are examined in (6) and (7) as follows:

\begin{tabular}{|c|c|c|c|c|c|c|c|c|c|c|}
\hline \multicolumn{11}{|c|}{ Sentential Strings as Compounds } \\
\hline \multicolumn{9}{|c|}{ Basic Form } & \multicolumn{2}{|c|}{ Phonetic Form } \\
\hline \multirow[t]{10}{*}{ (6) } & i. & Chúkwú & + & è-mé & + & kẹ́ & $\rightarrow$ & Chúkwúèmékẹ & $\rightarrow$ & [túkwêmếké] \\
\hline & & 'God' & & \multicolumn{4}{|c|}{ 'has-do' } & God has done so & & \\
\hline & ii. & Chí & + & nà & + & è-dú & $\rightarrow$ & Chínàèdú & $\rightarrow$ & [tginễdú] \\
\hline & & 'God' & & is & & \multicolumn{5}{|c|}{ 'is-helping' 'God helps.' } \\
\hline & iii. & nwá & + & à-má & + & ká & $\rightarrow$ & Nwáàmáká & $\rightarrow$ & [ywẫmấká] \\
\hline & & 'child' & & \multicolumn{4}{|c|}{ 'is-beautiful } & '(the) child is sc & ul' & \\
\hline & iv. & ò-bịà & + & gà & + & è-rí & $\rightarrow$ & Òbiàgàèrí & $\rightarrow$ & [òbjàgèrí] \\
\hline & & \multicolumn{9}{|c|}{ 'she-come' 'to 'eat-ing' 'she came to eat' } \\
\hline & v. & ònyé & + & mà & + & échí & $\rightarrow$ & Ònyémàéchí & $\rightarrow$ & [ònếmẽ̃týí] \\
\hline & & 'who' & & 'know & & 'tome & $\mathrm{w} /$ & 'who can foret & 'ton & w holds?' \\
\hline
\end{tabular}

Observe that in (6), the forenames, which exhibit some segmental and tonal processes (see the last column) are derived merely by a combination of syntactic strings, which, structurally, are sentences.

Similar strategy is employed in the derivation of numerals. For instance, to derive numerals above the non-base numerals 1 to 9 in Ėwùlù, the non-base are conflated with base numerals like 10, 20, 30 etc. Moreover, to derive numerals $11-19$, the base 10 is by rule added to the non-base numerals via the infixation of the conjunctive -nà- 'and' in between the base numeral and the non-base numerals. Consider the derivational patterns of the Ėwùlù numerals as follows: 


\begin{tabular}{|c|c|c|c|c|c|c|c|c|c|c|}
\hline \multicolumn{11}{|c|}{ Numerals as Compounds } \\
\hline \multicolumn{4}{|c|}{ Basic Form } & \multicolumn{4}{|c|}{ Compound Numeral } & \multicolumn{3}{|c|}{ Phonetic Form } \\
\hline (7) & i. & ìrí & + & nà & + & òfú & $\rightarrow$ & ìrínàòfú & $\rightarrow$ & [ìrínõ̃fú] \\
\hline & & 'ten' & & 'and' & & 'one' & & 'eleven’ & & 'eleven' \\
\hline & ii. & ìrí & + & nà & + & è̀bụ̀á & $\rightarrow$ & ìrínàẹ̀bụá & $\rightarrow$ & [ìrínẽ̀bwă] \\
\hline & & 'ten' & & 'and' & & 'two' & & 'twelve' & & 'twelve' \\
\hline & iii. & ìrí & + & nà & + & ìsé & $\rightarrow$ & ìrínàìsé & $\rightarrow$ & [ìrínĩ̀sé] \\
\hline & & 'ten' & & 'and' & & 'five' & & 'fifteen' & & 'fifteen' \\
\hline & iv. & óshú & + & nà & + & òfú & $\rightarrow$ & óshúnàòfú & $\rightarrow$ & [òfúnồfú] \\
\hline & & 'twenty' & & 'and' & & 'one' & & 'twenty-one' & & 'twenty-one' \\
\hline & $\mathrm{v}$. & óshú & + & nà & + & è̀bụ̀á & $\rightarrow$ & óshúnàẹ̀bụá & $\rightarrow$ & 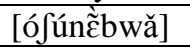 \\
\hline & & 'twenty' & & 'and' & & 'two' & & 'twenty-two' & & 'twenty-two' \\
\hline & vi. & óshú & + & nà & + & ìsé & $\rightarrow$ & óshúnàìsé & $\rightarrow$ & [ófúnî̃sé] \\
\hline & & 'twenty' & & 'and' & & 'five' & & 'twenty-five' & & 'twenty-five' \\
\hline
\end{tabular}

As shown in the data in (7), the established formula of deriving Èwùlù numerals depicts that numeral system thrives basically on compounding process.

\section{Phonological IMPLICATIONS OF COMPOUNDING In ÈWÙlù}

In many of the compound words espoused in (1) through (7), it will be noticed that some segmental and tonal processes occurred. These notable phonological patterns are simply the consequence of the operations of the process of compounding, which are examined below.

\subsection{Segmental Processes}

\subsubsection{Vowel Deletion}

Vowel deletion, a process which drops a vowel in (morpho-)phonological string, specifically affecting juncture vowels in Èwùlù is observed to regularly delete $\mathrm{V}^{1}$ rather than $\mathrm{V}^{2}$ (two vowel sequences) found at the boundary. $\mathrm{V}^{1}$ deletion applies if another vowel (i.e. $\mathrm{V}^{2}$ ) immediately follows it, otherwise the processes is deactivated (see particularly examples in (1i, iii, viii, $\mathrm{x}$ ). The pattern is described and analysed in (8) as follows:

\begin{tabular}{|c|c|c|c|c|c|c|c|c|}
\hline \multicolumn{9}{|c|}{ Juncture Vowel Deletion ( $\mathbf{V}^{1}$ Deletion) } \\
\hline \multirow[t]{2}{*}{ (8) } & \multicolumn{4}{|l|}{ A } & \multirow{2}{*}{$\begin{array}{ll}\text { B } \\
V^{1} \quad \text { Deletion } \\
\text { Process }\end{array}$} & & \multirow{2}{*}{$\begin{array}{l}\text { C } \\
\text { Output }\end{array}$} & \multirow{2}{*}{\begin{tabular}{l}
\multicolumn{1}{c}{ D } \\
The Deleted Juncture \\
Vowel
\end{tabular}} \\
\hline & Input & & & & & & & \\
\hline \multirow[t]{2}{*}{ i. } & /غेरó & + & únذ̀/ & $\rightarrow$ & 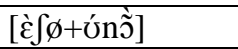 & $\rightarrow$ & [غेfớñ̃] & /ó/-deletion \\
\hline & 'body' & & 'house' & & & & 'wall' & \\
\hline \multirow[t]{2}{*}{ ii. } & léná & + & úkwú/ & $\rightarrow$ & ['́nø+úkwú] & $\rightarrow$ & [ع́nú́kwú] & /á/-deletion \\
\hline & 'eye' & & 'big' & & & & 'greed' & \\
\hline \multirow[t]{2}{*}{ iii. } & léká & + & íké/ & $\rightarrow$ & [Ék $\emptyset+1$ ké $]$ & $\rightarrow$ & [Ékí!ké] & lá/-deletion \\
\hline & 'hand' & & 'hard' & & & & 'stinginess' & \\
\hline \multirow[t]{2}{*}{ iv. } & 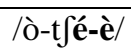 & + & ứǹ/ & $\rightarrow$ & 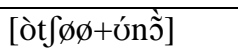 & $\rightarrow$ & 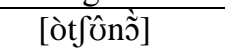 & /é/-/è/-deletion \\
\hline & 'guard' & & 'house' & & & & 'gecko' & \\
\hline \multirow[t]{2}{*}{ v. } & /ò-6ú-ù/ & + & èbùnù/ & $\rightarrow$ & [òbøø+èbùnũ் & $\rightarrow$ & [òbêbùnũ்] & /ú/-/ù/-deletion \\
\hline & 'killer' & & 'ram' & & & & 'native doctor' & \\
\hline
\end{tabular}

As the patterns in the examples in $(8, \mathrm{i}$-iii) show, it will be observed that, once two morphemes are merged to form a compound word (see column $B$ ), the $V_{1}$ is deleted, leaving the $V_{2}$ stable. Similarly, in the forms in $(8$, iv and $\mathrm{v})$, the $\mathrm{V}_{1}$ which is composed of double vowel is dropped, while $\mathrm{V}_{2}$ remain stable. Èwùlù employs boundary vowel deletion (hiatus resolution) for two principal reasons:

- To maintain its preference for CV over CVV syllable structure, a constraint that ensures that every syllable must maximally contain a consonant followed by a vowel in the language (Utulu, 2006; Utulu, 2015). For this reason, sequences of vowels resulting from the concantenation of morphological or syntactic strings are strategically simplified by shedding off the $\mathrm{V}_{1}$.

- To ensure faithfulness to the Obligatory Contour Prinicple (OCP), a universal grammar principle which regulates the occurrence of adjacent identical (segmental) features particularly at the phonetic level (McCarthy, 1986; Yip, 1988). Because the 'duplication problem' of hiatus, resulting from morpheme cocantenation violates the OCP, the principle simply deletes $\mathrm{V}_{1}$ in obedience to its strict constraint which sanctions adjacent distinct features but rules out adjacent identical features (Utulu, 2006; Aziza and Utulu, 2015). 


\subsubsection{Glide Formation}

Glide formation, a phonological process that converts [+high] either vowels /i/ or /u/ (together with other round vowels) to semiglides $[\mathrm{j}]$ or $[\mathrm{w}]$ respectively applied in the data. The process occurs as an alternative process to $\mathrm{V}_{1}$ deletion. High or rounded $\mathrm{V}^{1}$ typically converts to a glide, provided $\mathrm{V}_{2}$ is neither a high vowel, round vowel nor a syllabic consonant, otherwise $\mathrm{V}_{1}$ is deleted as illustrated in (8). In either cases, as suggested by (Utulu, 2006; Utulu 2015), the effect of the OCP is at work in order to resolve hiatus in Ewùlù . In some languages, however, $\mathrm{V}_{2}$ may be chosen as the deleted vowel or the gliding segment, in order to resolve hiatus (see Casali, 1996). Examples of morphophonologically induced glide formation process in which $/ \mathrm{u} /, / \mho /$ and $/ \mathrm{o} /$ are converted to $[\mathrm{w}]$ in Èwùlù compound words are presented in (9) as follows:

\begin{tabular}{|c|c|c|c|c|c|c|}
\hline \multicolumn{7}{|c|}{ Glide formation } \\
\hline (9) & & & & & Glide formation & The converted vowel \\
\hline \multirow[t]{2}{*}{ i. } & /ò-6ú-ù & + & ánò/ & $\rightarrow$ & [òbwânữ] & /ú-ù/ \\
\hline & 'killer' & & 'meat' & & 'butcher' & \\
\hline \multirow[t]{2}{*}{ ii. } & /ò-bú-ù & + & éfí/ & $\rightarrow$ & [òbwê!fí] & /ú/-/ù/ \\
\hline & 'killer' & & 'buffalo' & & 'a chieftaincy title' & \\
\hline \multirow[t]{2}{*}{ iii. } & lénú & + & ànì// & & [énwânì] & $/ \mathrm{ú} /$ \\
\hline & 'top' & & 'land' & & 'upland' & \\
\hline \multirow[t]{2}{*}{ vi. } & /غे̛̂́ & + & ókwó/ & $\rightarrow$ & 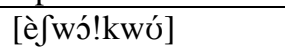 & /ư/ \\
\hline & 'body' & & 'fire' & & 'fever' & \\
\hline \multirow[t]{2}{*}{$\mathrm{V}$. } & Iưbó & + & ànì// & $\rightarrow$ & [úbwânị] & /ó/ \\
\hline & 'canoe' & & 'land' & & 'automobile' & \\
\hline
\end{tabular}

It will be observed that round vowels, whether high or non-high, become [w]. Though the case of /i/ or / $\mathrm{I} /$ convertion to [j] is amply attested in Ewulu (see Utulu, 2006; Utulu, 2015), its scantiness in the present work (see 2iv and 6iv) is a shere coincidence.

\subsubsection{Vowel Nasalisation}

Among the compound words presented in (2), (3), (6) and (7), it will be observed that a number of vowels prior to the operation of compounding process became phonetically nasalised, in a process referred to as vowel nasalisation. Vowel nasalisation is an assimilatory process whereby a nasal consonant transmits or spreads its nasalality property to a preceding or following oral vowel (Carr, 1993; Hyman, 1982). In the Ėwùlù data, in which the latter assimilatory process only applied, it is presumed to be principally triggered by morphological operations, since, as presented in (10), once two morphemes, or more than two morphemes, as in (6) and (7), are combined to form compounds, each $\mathrm{V}^{1}$ immediately preceded by a nasal consonant becomes deleted. The deletion consequently triggers the spread of nasalisation on the preserved $\mathrm{V}^{2}$ which hitherto was underspecified for [-nasal] feature. Examples of this pattern are presented in (10) as follows:

\begin{tabular}{|c|c|c|c|c|c|c|c|c|}
\hline \multirow[t]{2}{*}{$(10)$} & & & & \multicolumn{2}{|c|}{ Compound Form } & \multicolumn{3}{|c|}{ Phonetic Form } \\
\hline & \multicolumn{3}{|c|}{ Basic Form } & & $\mathbf{V}^{1}$ nasalisation & & $\mathbf{V}^{1}$ deletion & $V^{2}$ nasalisation \\
\hline i. & /énú & + & únò/ & $\rightarrow$ & [énứ̛́ñò̃] & $\rightarrow$ & [énøúnõ̀] & [énớñั่] \\
\hline & 'top' & & 'house' & & 'roof' & & & 'roof' \\
\hline ii. & /Éná & + & úkwú// & $\rightarrow$ & [ع́nã́úúkú] & $\rightarrow$ & [ع́nøúkwú] & [Énứkwú] \\
\hline & 'eye' & & 'big' & & 'greed' & & & 'greed' \\
\hline iii. & límé & + & únذ̀/ & $\rightarrow$ & [ímếúnỗ] & $\rightarrow$ & [ímøúnõ̀] & [ímớnวิ்] \\
\hline & 'in & & 'house' & & '(inner) room' & & & '(inner) room' \\
\hline iv & /Éná & + & úkwú// & $\rightarrow$ & [énấúúkwú] & $\rightarrow$ & [ćnøúkwú] & ['́nnứkwú] \\
\hline & 'eye' & & 'big' & & 'greed' & & & 'greed' \\
\hline
\end{tabular}

As it were, because the basis of vowel nasalisation is physiological, it will be observed too that final vowels in a number of compound words progressively acquire the nasality feature of preceding nasal consonants. The forms in (10i and iii) (and elsewhere in the present paper) depict this pattern, where the low-toned /亏/ preceded by $/ \mathrm{n} /$ became nasalised to /亏े/. It is worth mentioning that "regressive" vowel nasalisation process has not been reported to occur in Èwùlù

\subsection{Tonal Processes}

A number of tonal processes apply in Èwùlù as consequences of the operations of hiatus and glide formation via the compounding processes espoused in the foregoing. The following sections examine some of these tonal processes which Welmers (1973) refers to as morphotonemic alternations. 


\subsubsection{Tone Deletion}

As a number of data examined in (1) through (7) depicts, tone may delete from the phonetic string due to the operation of hiatus. For example, one of two adjacent tones may delete along with the $\mathrm{V}^{1}$ that bears it, if it is indentical with the one borne by $\mathrm{V}^{2}$. This pattern is viewed in current paper to be the effect of tonal OCP proposed by (Leben, 1973), which disallows the occurrence two adjacent identical tones/tonal features in a phonological representation. This is illustrated in (11) as follows:

\begin{tabular}{|c|c|c|c|c|c|c|c|c|}
\hline \multicolumn{9}{|c|}{ Tone Deletion as a Consequence of $\mathbf{V}^{1}$ Deletion } \\
\hline (11) & & & & & Vowel deletion & & Output & Affected Tone \\
\hline \multirow[t]{2}{*}{ i. } & lísí & + & íké/ & $\rightarrow$ & [ísøí!ké] & $\rightarrow$ & [ísí!ké] & high-toned $\mathrm{V}^{1} / \mathbf{1} /$ deleted \\
\hline & 'head' & & 'hard' & & 'stubbornness' & & & \\
\hline \multirow[t]{2}{*}{ ii. } & léná & + & úkwú/ & $\rightarrow$ & [ع́nøúkwú] & $\rightarrow$ & ['́núkwú] & lá/ deleted \\
\hline & 'eye’ & & 'big' & & 'greed' & & & \\
\hline \multirow[t]{2}{*}{ iii. } & léká & + & íkél & $\rightarrow$ & [ćkøíké] & $\rightarrow$ & [ع́kí!ké] & /á/ deleted \\
\hline & 'hand' & & 'hard' & & 'stinginess' & & & \\
\hline
\end{tabular}

Following from the examples, it will be observed that only high tone linked to $\mathrm{V}^{1}$ is deleted alongside its vowel. As mentioned above, this tonal process occurs only when the next tone (tone on $\mathrm{V}^{2}$ ) is identical to that of $\mathrm{V}^{1}$. Because both tones are the same, and are not allowed at the phonetic level in the language, one of them is therefore dropped in avoidance of the OCP violation. The OCP however appears to fail to delete identical high tones on $\mathrm{V}^{1}$ and $\mathrm{V}^{2}$, if the $\mathrm{V}^{2}$ is a syllabic nasal, /n/. The OCP effect seems to be inactive in this context, since, though both the $\mathrm{V}^{1}$ and $\mathrm{V}^{2}$ are identical in the feature specification for [+syll] but are distinct in the feature specification for [ \pm cons], $\mathrm{V}^{1}$ being [-cons] and $\mathrm{V}^{2}$ syllabic consonant, $/ \mathrm{n} /$ [+cons]. An example of this case is found in the forms [ónếńkúzí] 'teacher' and [ćkáń!rí] 'righ hand' in (1i and iii). The high tone on $\mathrm{V}^{1} / \tilde{e} /$ and /á/ in the respective examples is essentially not deleted by the OCP even though the high tone on the following /ń is identical with it.

\subsubsection{Tone Contraction (Fusion)}

Tone may contract or fuse together under the application of glide formation, also know as desyllabification rule, as some of the data examined in (1) through (7) show. The following examples in (12) depict this pattern:

\begin{tabular}{|c|c|c|c|c|c|c|c|c|}
\hline \multicolumn{9}{|c|}{ Tone Contraction as a Result of Gliding of $\mathbf{V}^{1}$} \\
\hline (12) & & & & & Compounding & & Glide of $/ \mathrm{i} /$ and $/ \mathrm{v} /$ & The contracted Tone \\
\hline i. & $\begin{array}{l}\text { ísí } \\
\text { 'head' }\end{array}$ & + & $\begin{array}{l}\text { ómá/ } \\
\text { 'beautiful' }\end{array}$ & $\rightarrow$ & $\begin{array}{l}\text { lísíómá/ } \\
\text { 'good-luck' }\end{array}$ & $\rightarrow$ & [ísjómấ] & $\begin{array}{l}\text { High tone on /í/ is } \\
\text { deleted sequel to } / 1 /- \\
\text { conversion to }[\mathrm{j}]\end{array}$ \\
\hline ii. & $\begin{array}{l}\text { lèfó } \\
\text { 'body' }\end{array}$ & + & $\begin{array}{l}\text { ókwól } \\
\text { 'fire' }\end{array}$ & $\rightarrow$ & 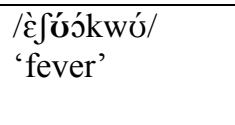 & $\rightarrow$ & {$\left[\dot{\varepsilon} \int \mathbf{v}\right.$} & $\begin{array}{l}\text { High tone on /ú/ is } \\
\text { deleted sequel to /ú/- } \\
\text { conversion to [w] }\end{array}$ \\
\hline iii. & $\begin{array}{l}\text { lḿfón!ló } \\
\text { 'seed' }\end{array}$ & + & $\begin{array}{l}\text { ósísí/ } \\
\text { 'stick/tree' }\end{array}$ & $\rightarrow$ & $\begin{array}{l}\text { /ḿfú!!lóósísíl } \\
\text { 'fruit' }\end{array}$ & $\rightarrow$ & [ḿfó!llw & $\begin{array}{l}\text { High tone on /ú/ is } \\
\text { deleted sequel to } / \mho /- \\
\text { conversion to }[\mathrm{w}]\end{array}$ \\
\hline
\end{tabular}

By observation of the pattern of tone contraction in the forth column, it will be noticed that tone contraction occurs if the $\mathrm{V}_{1}$ desyllabifies and its tone (in this wise the high tone on $\mathrm{V}_{1}$ ) is a copy of itself in $\mathrm{V}_{2}$. However, the recognized process which merges two identical high tones under the operation of glide formation may be blocked, if the adjoining tones are not identical. In this case, the language simply employ a different strategy, which is examined in the next section.

\subsubsection{Tone Segmentalisation (shift)}

One of the tonal patterns observed in the morphological data espoused in the foregoing is tone segmentalisation, or tone shift, using autosegmental term. Tone segmentalisation is a tonal process whereby one of two unidentical boundary level tones (high, low, or low, high sequence) is set afloat and subsequently docks on the next syllable (cf. Welmers, 1973), if the vowel that bore it deletes or desyllabifies. In other words, rather than the tone borne by the deleted or desyllabified vowel $\left(\mathrm{V}_{1}\right)$ delete along with it or remain stable, it simply shifts rightward and merges with the tone specified for $\mathrm{V}_{2}$ to yield a surface contour tone. This tonal pattern is illustrated in (13) and (14), as follows: 


\begin{tabular}{|c|c|c|c|c|c|c|c|c|c|c|}
\hline \multicolumn{11}{|c|}{ Tone Segmentalisation (shift) via V1 Deletion } \\
\hline (13) & \multirow[b]{2}{*}{ i. } & \multirow[b]{2}{*}{ /ò-bú-ù } & \multirow[b]{2}{*}{+} & \multirow[b]{2}{*}{ èbùnù/ } & \multirow[t]{2}{*}{$\begin{array}{l} \\
\rightarrow\end{array}$} & Co & apounding & & $\begin{array}{l}\text { Deletion of } \\
\text { V1 and high, } \\
\text { low tone } \\
\text { floating }\end{array}$ & \multirow[t]{2}{*}{$\begin{array}{c}\text { Tone } \\
\text { Segmentalisation } \\
\text { [òbêbùnũ்] }\end{array}$} \\
\hline & & & & & & /òb & ù̀èbùnù/ & $\rightarrow$ & /ò6"ebùnù/ & \\
\hline & & 'killer & & 'ram' & & & n killer' & & 'ram killer' & 'native doctor' \\
\hline & ii. & /ò-t féè-è & + & únذ̀/ & $\rightarrow$ & /òt & ¿̀̀ únذ̀/ & $\rightarrow$ & /òt $\int^{\prime}$ oǹ̀/ & [òtfônõ்] \\
\hline & & 'guard' & & 'house' & & 'ho & se guard' & & 'house guard' & 'gecko' \\
\hline & iii. & ywá & + & à-má & + & ká & $\rightarrow \quad$ /jwái & ákál & $\rightarrow$ /yw àmák & I/ [ywẫmấká] \\
\hline & & 'Child' & & $\begin{array}{l}\text { 'is- } \\
\text { beautifu }\end{array}$ & & 'mc & re than' & & & $\begin{array}{l}\text { '(the) child is } \\
\text { so beautiful' }\end{array}$ \\
\hline
\end{tabular}

As can be seen from the tonal pattern in (13i and ii), the V1 high, low tone sequence (see bold-faced vowels in first and third columns) is set afloat (in fourth column). Subsequently, the sequence effaces the tone on $\mathrm{V}^{2}$ and segmentalise on the $\mathrm{V}^{2}$ (see bold-faced vowels in the last column). The segmentalisation of lexical tones on surface forms thus yields falling contour tone. Similar contour effect on $\mathrm{V}^{2}$ shows up on compounds in which glide formation process applied, as the forms in (14) depict:

\begin{tabular}{|c|c|c|c|c|c|c|c|c|}
\hline \multicolumn{9}{|c|}{ Tone Segmentalisation (shift) via Glide Formation } \\
\hline$(14)$ & & & & & Compounding & & $\begin{array}{l}\text { Gliding of } \mathrm{V}^{1} \text { and } \\
\text { high tone floating }\end{array}$ & $\begin{array}{l}\text { Tone } \\
\text { Segmentalisation }\end{array}$ \\
\hline i. & $\begin{array}{l}\text { lúgbó } \\
\text { 'canoe', }\end{array}$ & + & $\begin{array}{l}\text { ànì/ } \\
\text { 'land' }\end{array}$ & $\rightarrow$ & $\begin{array}{l}\text { /úgbóànì/ } \\
\text { 'automobile' }\end{array}$ & $\rightarrow$ & [ưgbw' ànì] & $\begin{array}{l}\text { [úbwânì] } \\
\text { 'automobile' }\end{array}$ \\
\hline ii. & $\begin{array}{l}\text { lénú } \\
\text { 'top' }\end{array}$ & + & $\begin{array}{l}\text { ànì/ } \\
\text { 'land' }\end{array}$ & $\rightarrow$ & $\begin{array}{l}\text { lénúànì/ } \\
\text { 'name of a } \\
\text { tribe' }\end{array}$ & $\rightarrow$ & [énw'ànì] & $\begin{array}{l}\text { [énwânì] } \\
\text { 'name of a tribe' }\end{array}$ \\
\hline \multirow[t]{2}{*}{ iii. } & /ò-bú-ù & + & ánól & $\rightarrow$ & /òbúù ánớ/ & $\rightarrow$ & /òbw'anó/ & [ò6wânữ] \\
\hline & 'killer' & & 'meat' & & 'meat killer' & & & 'butcher' \\
\hline \multirow[t]{2}{*}{ iv. } & /ò-6ú-ù & + & éfí/ & $\rightarrow$ & /òbúùéfí/ & $\rightarrow$ & /òbw'efí/ & [òbwê!fí] \\
\hline & 'killer & & 'buffalow & & 'buffalow killer' & & & 'a chieftaincy title' \\
\hline
\end{tabular}

Like the pattern in (13), it will be observed that each tone on $\mathrm{V}_{1}$ (on the bold faced round vowels in the first and third columns) is set afloat sequel to the conversion of $\mathrm{V}_{1}$ to [w]. Subsequently, it shifts rightward and unites with the tone on $\mathrm{V}_{2}$ to yield a falling contour tone. For the forms derived from agentive nouns in (14 iii and iv), it will be noticed that, similar to the pattern in (13), the floating high, low tone sequence simply dislodges the tone on $V_{2}$. Clearly, the tonal patterns in (11) through (14) show that the stability or deletion of tone specified for $\mathrm{V}_{1}$ in Exùlù is dependent upon whether two or more adjacent tones are identical or distinct. The regulatory power of the OCP however underlies what particular pattern applies.

\subsubsection{Final High Tone Down Stepping}

One of the noticeable effects of compounding process on tones in Èwùlù is the downstepping of the high tone specified for the final syllable of com pound words. In a number compound words derived from noun-noun, noun-adjective sequence, final high tone preceded by another high tone, occurring on the right element of compounds, tends to downstep as $(\mathrm{H} ! \mathrm{H})$. This downstepping tonal process is exemplified in (15) as follows:

\begin{tabular}{|c|c|c|c|c|c|c|c|}
\hline$(15)$ & & & & & Compounding & & Final H tone ownstepping \\
\hline \multirow[t]{2}{*}{ i. } & /ókwú & + & ónú/ & $\rightarrow$ & /ókwúonứ/ & $\rightarrow$ & [ókwúó!nứ] \\
\hline & 'word' & & 'mouth' & & 'utterance' & & \\
\hline \multirow[t]{2}{*}{ ii. } & lèfú & + & ókwớ/ & $\rightarrow$ & lèfóókwứ/ & $\rightarrow$ & [è Jwớ!kwứ] \\
\hline & 'body' & & 'fire' & & 'fever' & & \\
\hline \multirow[t]{2}{*}{ iii. } & /ǹmáná & + & ńkú/ & $\rightarrow$ & /ǹmánáýkư/ & $\rightarrow$ & [m̀májã́ń!kư] \\
\hline & 'wine' & & 'wood' & & 'palmwine' & & \\
\hline \multirow[t]{2}{*}{ iv. } & /ćká & + & ńrí/ & $\rightarrow$ & /'́́káńrí/ & $\rightarrow$ & [ćkáń!rí] \\
\hline & 'hand' & & 'food' & & 'right hand' & & \\
\hline
\end{tabular}

However, if compound words are composed of noun-plus-adjective sequence, where the adjective denotes 'quantity' or 'quality', as in (16) below, the tonal rule that downsteps final high if preceded by a high tone like the forms in (15, i-iv) is blocked, thus ruling out impossible forms such as *[énû́!kwú] *[ísjó!mấ] for those in (16i and ii). This generalisation is supported by the exceptional 
case in (16iii), where the adjective iké 'hard' does not denote 'quantity' but a 'solid' element. Because ike does not denote 'quality' or 'quantity', this explains why the sequence of high tones on it is not downstepped, if combined with isi, otherwise the downstepping shound not necessarily occur in this context, as illustrated below:

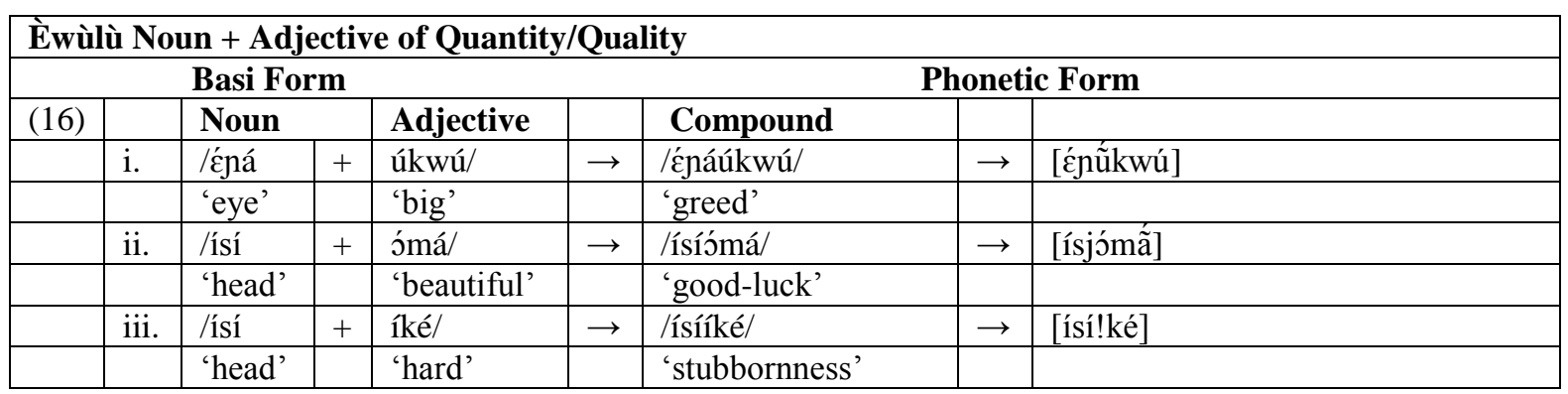

\section{SUMMARY AND CONCLUSION}

The paper has revealed that Èwùlù combines two or more words/morphemes to derive new words and consequently increase the range of its vocabulary, particularly where it lacks single lexical item to denote certain concepts. Moreover, the language has showed that its compound words are typically used for descriptive purposes. While some decribe animate and inanimate objects, others, especially, verbal compounds, depict an action. Besides, the article has exposed the fact longer strings which are functionally sentences can be strung together to form compound words. This is the case in the formation of forenames and numerals. Furthermore, the study has revealed the inevitable interface between morphology and phonology. Evidence of this fact is supported by a number of phonological processes which are wider implications of the language compounding system. In this regard, three morphologically-induced segmental processes: boundary vowel deletion, glide formation and vowel nasalisation processes were indentified and analysed. The effect which these segmental processes have on the structure of lexical tones of the morphemes which were combined to form compounds were explored. The resultant modification of lexical tones culminated in four tonal processes. They are (1) tone deletion, (2) tone contraction, (3) tone segmentalisation, and (4) word final high tone downstepping.

Having examined some of the notable patterns of creating new words via compounding process in Èwùlù, and how the divers morphological patternings drive certain phonological processes, it is recommended that more research attention be given to small languages in order to bring them to lime light and hence encourage rigorous researches on them, a step which will enhance their continuous documentation and development, as any languages that must survive the negative effects of globalisation must be necessarily have written tradition. But until small languages which are the ones most vulnerable to extinction are given the due rigorous research attention, they stand the risk of eventually becoming moribund languages, largely due to lack of codification. The Nigerian major languages, such as Hausa, Igbo and Yoruba as well as the 'big' languages of international economy such as English, French, German, Italian, Spanish, Japanes and Chinese, among a few others, have become very popular both in domestic and international affairs just because they have enjoyed continuous documentation and developement, especially the foreign languages.

\section{REFERENCES}

[1] Aikhenvald, A. 2007. Typological distinctions in word-formation. In T. Shopen (ed.) Language typology and syntactic description: Volume III: Grammatical categories and the lexicon. Cambridge: Cambridge University Press. P.1-65.

[2] Aziza, R. O and Utulu, D.C. Compounding in Ewulu and Urhobo. To appear in the International Journal of Research in Humanities and Social Sciences (IJRHSS) Vol. 2, 6.

[3] Carr, P. 1993. Modern linguistics phonology. The Macmillan Press Ltd.

[4] Casali, R.F. 1996. Resolving hiatus. Doctoral dissertation, UCLA.

[5] Emenanjo, N. 1978. Elements of Igbo grammar. Ibadan, Oxford University Press.

[6] Fabb, N. 2001. Compounding, in Spencer A. and A.M Zwicky (eds.) The handbook of morphology. Oxford. UK: Blackwell Publishers, p. 66-83.

[7] Hyman, L. 1982. The representation of nasality in Gokana. In Van der Hulst and Smith (eds), Part I: p. 111-130. 
[8] Iloene, M and Yusuf, O. 2010. Morphology. In Baisc linguistics for Nigerian languages, O. Yusuf (ed.), NILAN: p. 66-81.

[9] Katamba, F. 1993. Mordern linguistics morphology. London: Macmillan Press Limited.

[10] Leben, W. 1973. Suprasegmental phonology. Doctoral dissertation, MIT, Cambridge, MA. Distributed by the Indiana University Linguistics Club.

[11] McCarthy, J. J. 1986. OCP effects:gemination and antigemination. Linguistic Inquiry: 17: p. $207-263$.

[12] Utulu, D. C. 2006. OCP effects: elision and glide formation in Èwùlù. Awka Journal of Linguistics and Languages 2: p. 109-118.

[13] _2014. Ewulu tone system: a preliminary investigation. To appear in the University of Uyo Journal of Humanities, Faculty of Arts, University of Uyo, Uyo, Nigeria.

[14] 2015. Hiatus resolution strategies and the obligatory contour principle: Ewulu as a case study. To appear in the International Journal of Research in Humanities and Social Sciences (IJRHSS) Vol. 2, 6 .

[15] Welmers, W. E. 1973. African language structures. Berkeley: University of California Press (CUP).

[16] Williamson, K. 1992. Reading, writing and publishing in small languages. In Teaching Nigerian

[17] Languages: Experiences from the Delta. Rose Aziza and Nolue Emenanjo (eds.) Emba

[18] Printing and Publishing Company Ltd., Onitsha.

[19] Yip, M. 1988. The obligatory contour principle and phonological rules: A loss of identity. In Linguistic inquiry 19: p. 65-100.

\section{AUTHOR'S BIOGRAPHY:}

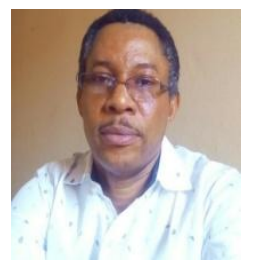

Utulu, Don C. (Senior Lecturer), Lecturer of Linguistics, Department of Languages and Linguistics, Delta State University, Abraka, Delta State, Nigeria.

Citation: Utulu, Don C., Ph.D.. "The Patterning of Segments and Tones in Èwùlù Compounding Process". International Journal of Humanities Social Sciences and Education (IJHSSE), vol 5, no. 3, 2018, pp. 150-159 doi: http://dx.doi.org/10.20431/2349-0381.0503016.

Copyright: (C) 2018 Authors. This is an open-access article distributed under the terms of the Creative Commons Attribution License, which permits unrestricted use, distribution, and reproduction in any medium, provided the original author and source are credited. 